Лідер. Еліта.Суспільство

Leader. Elite. Society

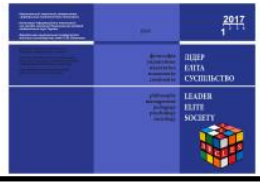

УДК 351:332.12: 331.2

doi: 10.20998/2616-3241.2018.1.08

\title{
Олександр Мельниченко
}

доктор наук з державного управління, професор, професор кафедри громадського здоров'я та управління охороною здоров'я, Харківський національний медичний університет, Харків, Україна

ORCID:0000-0001-5021-9025

E-mail:mel_doc@ukr.net

\section{КИЇВ - ЛІДЕР СЕРЕД РЕГІОНІВ УКРАЇНИ ЗА РІВНЕМ ЗАРОБІТНИХ ПЛАТ: ПУБЛІЧНО-УПРАВЛІНСЬКИЙ ВИМІР}

Анотація: Порівняно розмір заробітних плат в різних регіонах України; систематизовано причини та наслідки існуючого переважання Кисва над іншими регіонами України за рівнем заробітних плат; конкретизовано перелік специфічних засобів (у межах визнаних механізмів) публічного управління щуодо розміру заробітних плат; упорядковано перелік пріоритетних напрямів такого управлінського впливу.

Ключові слова: публічне управління, заробітна плата, Киї, регіон, лідер.

\section{Olexander Melnychenko}

Doctor of Sciences in Public Administration, Full Professor, Full Professor of Public Health and Healthcare Management, Kharkiv National

Medical University, Kharkiv, Ukraine

E-mail:mel_doc@ukr.net

\section{KYIV - LEADER AMONG UKRAINIAN REGIONS BY THE SALARIES LEVEL: PUBLIC-ADMINISTRATIVE DIMENSION}

Abstract: The size of salaries in different regions of Ukraine was compared; causes and consequences of Kyiv's existing predominance over other Ukrainian regions by the salaries level were systematized; the list of means (in frames of the determined mechanisms) of public administration of the salaries size was concretized; the list of major priorities of such administrative influence was sorted.

Keywords: public administration, salary, Kyiv, region, leader.

\section{OlexanderMelnychenko}

An extended abstract of the paper on the subject of:

"Kyiv - leader among Ukrainian regions by the salaries level: public-administrative dimension"

Problem setting. Since payments for labor traditionally make more than a half in the comprehensive income of Ukrainian population, therefore analysis of not only the

(C) Олександр Мельниченко, 2018 
dynamics of the salary size on average in the country, but in terms of its individual regions aroses particular interest. All of the above is caused, at least, by the fact, that the existing differentiation of regions by these important indicators is at the same time the consequence, form of manifestation and prerequisite for further intensification of the regional development disproportions and stratification of the population due to the level of its wel-being. Considering the stated perspective of the research, let us, above all, focus on Kyiv phenomenon as a leader among Ukrainian regions in terms of salaries level.

Recent research and publications analysis. Different aspects of public administration of the earned income formation in Ukraine became a corner stone of a number of theses. However, the scientists still show interest in researching the problem range in question, which is proved by numerous publications in specialized editions. Giving credit to the domestic scholars' efforts, due attention should be paid to scarcity of complex research in the field, and therefore to the necessity of developing scientific surveys of the domain.

Paper objective. The aim of the article is to develop recommendations, aimed at the lessening of negative effects from the intensification of disproportions by the salaries level in Kyiv in comparison with other Ukrainian regions. To achieve this goal it is necessary to solve such tasks: 1) to compare the salaries size in different regions of Ukraine; 2) to systematize causes and consequences of Kyiv's existing predominance over other Ukrainian regions by the salaries level; 3) to concretize the list of means (in frames of the determined mechanisms) of public administration of the salaries size; 4) to sort out the list of major priorities of such administrative influence.

Постановка проблеми в загальному вигляді та ii зв'язок із важливими науковими чи практичними завданнями.
Paper main body. The data analysisof the State Statistics Service of Ukraine allowed to determine tendencies concerning the size of a nominal salary in Ukraine and in its individual regions during 2002-2018. Disproportions of criteria of the index observed in different regions were determined. The regions, which appear to be "leaders" and "outsiders" were singled out. The mechanisms of influence on the size of a salary were visualized. Universal and specific methods and techniques, used by every subjet of public administration to perform control functions in frames of the determined mechanisms of influence were systematized. Major priorities of such influence were listed.

Conclusions of the research. Kyivisa permanent evident "leader" among Ukrainian regions by the average monthly salary, though its advantage over "outsiders" is being gradually reduced. This situation is caused by the influence of administrative, geographic, economic and other factors on the one hand and it leads to further increase of labor incomes and enhancing competition at the capital labour-market. Existing interregional (inter-branch) differences of the salaries size, caused by the influence of market mechanisms and mechanisms of public administration. Authorized personsusecorresponding mechanisms and means of public administration for ensuring the increase of the level of salaries due to major priorities. At the same time general and local government mostly uses administrative, organizational and legal mechanisms; business structures use economic ones, and public organizations use social psychological mechanisms of influence. Thecontinuationofscientificresearchesonthegivenperspectivewillpromotefurtherincreaseof the well-being level of Ukrainian population, includingthe improvementof public administration in this field.

Для задоволення своїх зростаючих потреб людині потрібні відповідні блага та кошти для їх придбання. Оскільки в структурі 
сукупних доходів населення України традиційно "більш як половину становить оплата праці" [1], тому неабиякий інтерес викликає аналіз не лише динаміки розміру заробітної плати у середньому на території країни, а і у розрізі окремих іiі регіонів. Означене обумовлено, щонайменше, тим, що існуюча диференціація регіонів за цим важливим показником $\epsilon$, водночас, наслідком, формою прояву та передумовою подальшого поглиблення диспропорцій розвитку регіонів і розшарування його населення за рівнем добробуту.

Принагідно зазначимо, що навіть пересічному громадянину відомо: кращі заробітки в містах, а найвищі - у столиці та закордоном. Проте далеко не всі задумувались: чому саме так? Зважаючи на заявлену проблематику дослідження, зосередимось, передусім, на феномені Києва як лідера серед регіонів України за рівнем заробітних плат.

Аналіз останніх досліджень і публікацій, у яких започатковано розв'язання цієї проблеми і на які спирається автор. Проблематика особливостей формуванням трудових доходів в Україні стала наріжним каменем дисертаційних досліджень (Beрич Ю., Гнатишин Й., Гордієнко Л., Дворник I., Заяць В., Кролевець О., Кухарєва О., Простотіна С., Стожок О., Тимченко Б., Федірко Н., Швабій К. та ін.).

Дефіцит комплексних досліджень за даною проблематикою певною мірою компенсується публікаціями у фахових виданнях таких науковців: Балакірєва O.M., Гвелесіані А., Гончаров С., Дем'янчук I., Додонов О., Звягільський Ю., Ільєнко Н., Кір'ян В., Куліков Г., Кустовська О., Литвин І., Лібанова Е., Новак І., Новіков В., Ноур А.М.,Романюк Р., Спасенко Ю., Халецька А., Цимбалюк С., Ціщик Р., Шульгінова Л. тощо.

Виділення не вирішених раніше частин загальної проблеми, котрим присвячується дана стаття. Віддаючи належне напрацюванням вітчизняних науковців за досліджуваною проблематикою, слід наголосити, що на сьогодні недостатньо до- слідженими лишаються механізми публічного управління диспропорціями за рівнем заробітних плат.

Формулювання цілей статті. Постановка завдання. Метою статті $\epsilon$ розробка рекомендацій, спрямованих на зменшення негативних ефектів від посилення диспропорцій за рівнем заробітних плат у Києві порівняно 3 іншими регіонами України. Для досягнення цієї мети необхідно вирішити такі завдання: 1) порівняти розмір заробітних плат в різних регіонах України; 2) систематизувати причини та наслідки існуючого переважання Києва над іншими регіонами України за рівнем заробітних плат; 3) конкретизувати перелік специфічних засобів (у межах визнаних механізмів) публічного управління розміром заробітних плат; 4) упорядкувати перелік пріоритетних напрямів такого управлінського впливу.

Виклад основного матеріалу дослідження 3 повним обгрунтуванням отриманих наукових результатів. Прагнення населення покращувати власне життя має спиратися на відповідне підвищення своїх прибутків. Певною мірою це стає реальністю завдяки підвищенню розміру заробітних плат. Аналіз даних Державної служби статистики України [1] дозволив виявити таке: упродовж 20022018 pр. номінальна заробітна плата в Україні зросла більш як у 24 рази, тоді як їі доларовий еквівалент - у 4,5 рази; номінальні величини зростали постійно, натомість "доларовий" еквівалент заробітної плати істотною мірою залежав від курсу гривні до ВКВ (особливо наочно це проявилось у 2009 р. та 2015 р.) (табл. 1); наявність істотної розбіжності розміру середньої місячної заробітної плати в різних регіонах; незмінність явних "лідера" (м. Київ) i "аутсайдера" (Тернопільська область) супроводжується певними переміщеннями за місцями (виключенням $\epsilon$ лише Донецька область, яка стабільно займає друге місце) обмеженого переліку областей; приналежність до регіонів - "лідерів" індустріально та фінансово розви- 
нених територій (м. Київ, Дніпропетровська, Донецька, Запорізька, Київська, Луганська та Миколаївська області), а також до регіонів - "аутсайдерів" - регіони з домінуванням аграрного сектору (Вінницька, Волинська, Житомирська, Закарпатська, Кіровоградська, Тернопільська, Херсонська, Хмельницька, Чернігівська та Чернівецька області); частіше за все лише регіони - "лідери" (і то не завжди) мають результат, що перевищує середній на те- риторії країни, натомість решта регіонів помітно відстають від нього; відсутність істотних відмінностей (винятком є лише м. Київ) між регіонами як серед "лідерів", так і "аутсайдерів"; упродовж 20022018 pр. заробітна плата в м. Київ зросла у 21,4 рази, тоді як в Тернопільській області у 31,8 рази, завдяки чому розрив між цими регіонами скоротився на третину (до 198,9 \%) (табл. 2).

Таблиця 1. - Динаміка середньої місячної заробітної плати в Україні (станом на 01 січня)

(розраховано за даними [1] та результатами власного моніторингу курсу валют

\begin{tabular}{|c|c|c|}
\hline \multicolumn{3}{|c|}{ в Україні) } \\
\hline Роки & Номінальна, $\mathbf{z}$ & Еквівалентна, \$ \\
\hline 2002 & 321 & 60,6 \\
\hline 2003 & 401 & 73,7 \\
\hline 2004 & 500 & 92,9 \\
\hline 2005 & 641 & 125,1 \\
\hline 2006 & 865 & 168,0 \\
\hline 2007 & 1112 & 219,8 \\
\hline 2008 & 1521 & 300,0 \\
\hline 2009 & 1665 & 239,6 \\
\hline 2010 & 1916 & 239,5 \\
\hline 2011 & 2297 & 287,8 \\
\hline 2012 & 2722 & 337,7 \\
\hline 2013 & 3000 & 372,7 \\
\hline 2014 & 3167 & 384,8 \\
\hline 2015 & 3455 & 178,6 \\
\hline 2016 & 4362 & 169,7 \\
\hline 2017 & 6008 & 216,0 \\
\hline 2018 & 7711 & 274,6 \\
\hline
\end{tabular}

Таблиця 2. - Середня місячна заробітна плата в регіонах України (станом на 01 січня), Ұ (за даними [1])

\begin{tabular}{|c|c|c|c|}
\hline Роки & Україна & Регіони - "лідери" & Регіони - "аутсайдери" \\
\hline 2002 & 321 & $\begin{array}{l}545 \text { - м. Київ } \\
400 \text { - Донецька обл. } \\
387 \text { - Запорізька обл. } \\
384 \text { - Дніпропетровська обл. } \\
343 \text { - Миколаївська обл. } \\
\end{array}$ & $\begin{array}{l}220 \text { - Чернівецька обл. } \\
215 \text { - Хмельницька обл. } \\
212 \text { - Вінницька обл. } \\
206 \text { - Волинська обл. } \\
184 \text { - Тернопільська обл. }\end{array}$ \\
\hline 2007 & 1112 & $\begin{array}{l}1865 \text { - м. Київ } \\
1280 \text { - Донецька обл. } \\
1229 \text { - Дніпропетровська обл. } \\
1166 \text { - Запорізька обл. } \\
1119 \text { - Луганська обл. }\end{array}$ & $\begin{array}{l}826 \text { - Херсонська обл. } \\
825 \text { - Волинська обл. } \\
822 \text { - Вінницька обл. } \\
820 \text { - Чернігівська обл. } \\
760 \text { - Тернопільська обл. }\end{array}$ \\
\hline
\end{tabular}




\begin{tabular}{|c|c|c|c|}
\hline 2012 & 2722 & $\begin{array}{l}4148 \text { - м. Київ } \\
3151 \text { - Донецька обл. } \\
2860 \text { - Дніпропетровська обл. } \\
2842 \text { - Луганська обл. } \\
2829 \text { - Київська обл. }\end{array}$ & $\begin{array}{l}2067 \text { - Чернівецька обл. } \\
2062 \text { - Волинська обл. } \\
2039 \text { - Чернігівська обл. } \\
2018 \text { - Херсонська обл. } \\
1941 \text { - Тернопільська обл. }\end{array}$ \\
\hline 2017 & 6008 & $\begin{array}{l}9292 \text { - м. Київ } \\
6503 \text { - Донецька обл. } \\
6160 \text { - Київська обл. } \\
5905 \text { - Дніпропетровська обл. } \\
5831 \text { - Запорізька обл. }\end{array}$ & $\begin{array}{l}4871 \text { - Житомирська обл. } \\
4867 \text { - Херсонська обл. } \\
4758 \text { - Чернігівська обл. } \\
4717 \text { - Чернівецька обл. } \\
4641 \text { - Тернопільська обл. }\end{array}$ \\
\hline 2018 & 7711 & $\begin{array}{l}11668 \text { - м. Київ } \\
8389 \text { - Донецька обл. } \\
8145 \text { - Київська обл. } \\
7839 \text { - Дніпропетровська обл. } \\
7479 \text { - Запорізька обл. } \\
\end{array}$ & $\begin{array}{l}6221 \text { - Кіровоградська обл. } \\
6098 \text { - Чернігівська обл. } \\
6063 \text { - Херсонська обл. } \\
5914 \text { - Чернівецька обл. } \\
5865 \text { - Тернопільська обл. }\end{array}$ \\
\hline
\end{tabular}

Об'єктивна оцінка ситуації у цій царині (передусім, щодо розміру фактичних прибутків і витрат населення) $є$ проблематичною через таке: відсутність можливості порахувати "тіньові" трудові прибутки (за оцінками МВФ "рівень тінізації української економіки становить 42,9\%" [2]); істотні масштаби внутрішньої та зовнішньої трудової міграції; невідповідність (передусім, за масштабом) між Києвом як адміністративно-територіальною одиницею і як мегаполісом (чимало тих, хто працює в Києві, фактично живуть у його передмісті чи містах-супутниках) та іншими містами.

Попри ці методологічні недоліки, можемо однозначно стверджувати: Київ незмінний явний "лідер" серед регіонів України за розміром середньої місячної заробітної плати. У чому ж причина такої ситуації? Радше за все, їх декілька:

- істотна централізація влади спричиняє до концентрації адміністративного та фінансового ресурсів, а з тим - формування високооплачуваних посад для тих, хто розпоряджається цими ресурсами;

- статус (столиця), географічне розташування (перетин транспортних шляхів) та наявність інших переваг (значна площа, розвинена соціальна інфраструктура тощо) обумовлюють розміщення значної кількості й різних за розміром $\mathrm{i}$ галузевою приналежністю суб'єктів господарювання, що здійснюють свою діяльність на цій території.

Вищенаведені ознаки носять переважно загальний характер й конкретизуються у наслідках, що впливають на розмір заробітних плат і столичний ринок праці загалом:

- через тісний прямий зв'язок між розміром прибутків (зокрема трудових) i вартістю життя кияни та заробітчани мають враховувати, що ціни на харчі та транспортне забезпечення $є$ вищими, а на житло - у декілька разів вищі за ті, що чинні в інших регіонах (тобто, певна сума в Києві та в іншому населеному пункті України мають різну цінність); вищі заробітки спонукають населення до активнішого споживання, забезпечуючи розвиток, передусім, торгівлі та сфери послуг;

- наявність надлишку робочої сили (зокрема висококваліфікованої) створює не лише нові можливості для бізнесу, а й посилює конкуренцію на цьому ринку (почасти, киян "витісняють" 3 робочих місць трудові мігранти, котрі погоджуються на гірші умови праці та нижчу заробітну плату); до речі, частину своїх прибутків трудові мігранти переказують своїм родинам, тим самим покращуючи 
життя в інших регіонах; завдяки трудовим мігрантам не лише створюються додаткові робочі місця (формуються трудові прибутки) у суміжних сферах (оренда житла, транспортне забезпечення, швидке харчування тощо), а й зростають масштаби неофіційної зайнятості, погіршується (на підгрунті національних, релігійних, економічних чи інших протиріч) криміногенна ситуація.

- порівняно висока заробітна плата, 3 одного боку, підвищує собівартість продукції (фактично, тисне на іiї ціну), а 3 іншого - $\epsilon$ дієвим стимулом для розміщення виробничих потужностей в регіонах, що може позитивно позначитись на прибут- ках їхнього населення та конкурентоспроможності власної продукції;

- значна кількість добре оплачуваних робочих місць $\epsilon$ чудовою основою для формування прибуткової частини місцевого бюджету, а з тим - вирішення нагальних соціальних та економічних проблем територіальної громади, й подальшого розвитку Києва.

Вищенаведені причини й наслідки відмінностей розміру заробітних плат у м. Київ та в інших регіонах країни обумовлені впливом ринкових і механізмів публічного управління (рис. 1).

\begin{tabular}{|c|c|c|}
\hline Попит на робочу силу & Пропозиція робочої сили & Конкуренція на ринку праці \\
\hline \multicolumn{3}{|c|}{ Ринкові механізми } \\
\hline \multicolumn{3}{|c|}{ 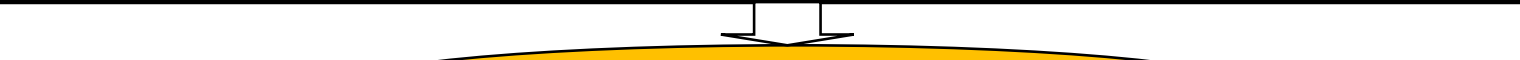 } \\
\hline \multicolumn{3}{|c|}{ ЗАРОБІТНА ПЛАТА } \\
\hline \multicolumn{3}{|c|}{7} \\
\hline \multicolumn{3}{|c|}{ Механізми публічного управління } \\
\hline $\begin{array}{r}\text { За суб'єктом } \\
\text { - органи державного упр } \\
\text { - органи місчевого самов } \\
\text { - бізнес-структури; } \\
\text { - громадські організації. }\end{array}$ & $\begin{array}{l}-a d \\
-e \kappa \\
-o p \\
-c o\end{array}$ & $\begin{array}{l}\text { За способом впливу: } \\
\text { ративні; } \\
\text { ні; } \\
\text { iйно-правові; } \\
\text {-психологічні. }\end{array}$ \\
\hline
\end{tabular}

Рис. 1. - Механізми впливу на розмір заробітної плати

Проведені узагальнення [3, с. 6971] дозволили, по-перше, систематизувати основні функції ринкових і механізмів публічного управління; по-друге, з'ясувати, що ці механізми не лише усувають негативні прояви неспроможностей, відповідно, держави та ринку, а й забезпечують розвиток об'єкта управління (у контексті даного дослідження - підвищення розміру заробітних плат).

Кожний суб'єкт публічного управління використовує універсальні та специфічні способи й прийоми для виконання функцій управління у рамках визнаних механізмів впливу (рис. 1):

- адміністративні: державний контроль і перевірки суб'єктів господарю- вання щодо умов праці, офіційності працевлаштування, розміру заробітної плати та своєчасності їі виплати; подання до суду позовів про відшкодування шкоди, заподіяної особам, що працюють; регулювання фондів оплати праці підприємствмонополістів;

-економічні: фінансування фонду оплати праці; оподаткування доходів працівників; індексація заробітних плат; надання податкової знижки; попередження та штрафи за правопорушення; компенсація працівникам втрати частини заробітку у зв'язку зі затримками термінів його виплати;

- організаційно-правові: Конституція України, Кодекс України, Закони України, Укази Президента України, поста- 
нови та рішення Верховної Ради України, постанови та розпорядження Кабінету Міністрів України; нормативні акти центральних органів виконавчої влади, обласних і районних державних адміністрацій; розпорядження та рішення органів місцевого самоврядування, керівництва бізнесструктур та/чи громадських організацій; реєстрація, облік, аналіз і реагування на заяви, скарги та пропозиції населення щодо умов праці, офіційності працевлаштування, розміру заробітної плати та своєчасності іiі виплати; навчання, підготовка, перепідготовка та підвищення кваліфікації; конкурси на заміщення вакантних посад; штатні розклади суб'єкта господарювання; участь у переговорах щодо укладення Генеральної та галузевих тарифних угод; установлення розміру мінімальної заробітної плати та інших соціальних норм і гарантій; затвердження єдиної тарифної сітки; встановлення умов і розмірів оплати праці керівників підприємств державної та комунальної форми власності, працівників підприємств (організацій, установ), що фінансуються чи дотуються 3 бюджету; створення нових і збереження наявних робочих місць; адаптування до умов України, використання передового світового досвіду в цій сфері, а також використання надбання вітчизняної науки та практики; розробка обгрунтованих нормативів витрат на робочу силу та їх основних компонентів, що враховують особливості життєдіяльності працівників і забезпечують соціальні гарантії;

- соціально-психологічні: соціальні норми; виховання; переконання; психологічні настанови; роз'яснення; суспільний тиск; переговори; спонукання до більш продуктивної праці.

Узагальнення напрацювань провідних вітчизняних науковців і результати власних досліджень дозволяють стверджувати, що подальше підвищення розміру заробітної плати в Україні можливе завдяки реалізації комплексу заходів публічного управління за такими пріоритетними напрямами: стабільності;

- забезпечення макроекономічної

- реалізація дієвої структурної пере-

будови економіки, реструктуризації, модернізації, підприємств, інноваційного розвитку виробництва;

- застосування економічно обгрунтованої та законодавчо закріпленої соціально справедливої диференціації заробітної плати;

- удосконалення системи освіти, підготовки й перепідготовки кадрів, стимулювати роботодавців і працездатних осіб до підвищення якості робочої сили;

- покращення умов для отримання трудових прибутків населення;

- збільшення розміру заробітних плат;

- захист працівників від необгрунтованих звільнень, неповної офіційної зайнятості та застосування жорсткої системи важелів і механізмів інтенсифікації праці;

- детінізація зайнятості та трудових прибутків населення.

Висновки 3 даного дослідження i перспективи подальших розвідок. Київ $\epsilon$ незмінним явним "лідером" серед регіонів України за розміром середньої місячної заробітної плати, хоча його перевага над "аутсайдерами" поступово скорочується. Означена ситуація, з одного боку, обумовлена впливом адміністративних, географічних, економічних та інших чинників, а 3 іншого - спричинює подальше підвищення трудових прибутків і посилення конкуренції на столичному ринку праці. Існуючі міжрегіональні (міжгалузеві) відмінності розміру заробітних плат обумовлені впливом ринкових і механізмів публічного управління. Уповноважені суб'єкти використовують відповідні механізми та засоби публічного управління для забезпечення підвищення рівня заробітних плат за пріоритетними напрямами. При цьому органи державного управління та органи місцевого самоврядування здебільшого використовують адміністративні та організаційно-правові механізми; бізнес-структури - економічні, а громадські 
організації - соціально-психологічні механізми впливу. Продовження наукових розвідок за даною проблематикою сприятиме подальшому підвищенню рівня доб-

\section{Список літератури}

1. Державний комітет статистики України. [Електронний ресурс]. Офіційний сайт. Режим доступу: http://www.ukrstat.gov.ua/

2. МВФ оценил масштабы теневой экономики в Украине: названы цифры. [Електронний ресурс]. Режим доступу:https://economy.apostrophe.ua/new s/promyshlennost/2018-02-10/mvf-otsenil masshtabyi-tenevoy-ekonomiki-v-ukrainenazvanyi-tsifryi-/121068 (дата звернення 11.02.2018)

3. Мельниченко, О.А. (2013) Управління структурними зрушеннями: підручник. Х.: Оберіг, 300 с.

\section{References}

1. Derghavnyy komitet statystyky Ukrayiny. [State Statistics Committee of Ukraine] Ofitsiynyy sait. URL: робуту населення України, зокрема за рахунок удосконалення публічного управління у цій царині.

http://www.ukrstat.gov.ua/operativ/operativ (data zvernennya -01.07.2018) [in Ukrainian].

2. MVF otsenil masshtaby tenevoy ekonomiky $v$ Ukraine: nazvany tsyfry. [ The IMF estimated the scale of the shadow economy in Ukraine: numbers are named. ] URL: https://economy.apostrophe.ua/news/promys hlennost/2018-02-10/mvf-otsenilmasshtabyi-tenevoy-ekonomiki-v-ukrainenazvanyi-tsifryi-/121068 (data zvernennya 11.02.2018) [in Russian].

3. Melnychenko O.A. Upravlinnya strukturnymy zrushennyamy: pidruchnyk. [Structural Shift Management: A Tutorial.] Kharkiv, 2013. 300 s. [in Ukrainian].

Стаття надійшла до редколегї: 14.05.2018 